\title{
Effects of Media Advertising On Consumers' Purchase Intent in Awka, Anambra State: A Study of Hero Beer.
}

\author{
Ugonna, Ikechukwu $\mathrm{A}^{1}$, Okolo, Victor $\mathrm{O}^{2}$, Obikeze, Chinedum $\mathrm{O}^{3}$, \\ Ohanagorom Millicent ${ }^{4}$, Nwodo Sylvanus I ${ }^{5}$,Oranusi, Ifeanyichukwu $\mathrm{N}^{6}$ \\ ${ }^{I}$ Senior Lecturer, Department of Marketing, Chukwuemeka Odumegwu Ojukwu University, Uli. \\ ${ }^{2}$ Lecturer, Department of Marketing, University of Nigeria Nsukka. \\ ${ }^{3}$ Senior Lecturer, Department of Marketing, Chukwuemeka Odumegwu Ojukwu University, Uli. \\ ${ }^{4}$ Graduate Assistant/ Ph.D Student, Department of Marketing University of Nigeria, Nsukka. \\ ${ }^{5}$ Ph.D. Student, Department of Marketing, Federal University of Agriculture, Umudike \& \\ ${ }^{6}$ Ph.D. Student, Department of Marketing, Chukwuemeka Odumegwu Ojukwu University, Uli.
}

\begin{abstract}
The effects of media advertising on Hero beer on consumers' purchase intent in Awka, Anambra State, were tested in this study, using the AIDCA theory of advertising, an extension of AIDA. AIDCA is an acronym for the attention, interest, desire, conviction, and action which an advertisement is expected to induce in consumers. The study focused on the effects which the variables of media advertising (TV, radio, and billboard) had on beer consumers' purchase intent of Hero beer, using the AIDCA model, as well as the effect of a combination of these variables (media-mix) on purchase intent. Through a survey of a judgementally determined sample of 200 beer consumers in the study area, the study used questionnaire to generate the required data. Using a linear regression model, the media advertising variables significantly explained $50 \%(R$ Squared $=.506$ \&.494) of the variability in the consumers' purchase intent and AIDCA, the dependent variables. The $R$ Squared was largely attributable to all but one of the media advertisements. In other words, the findings of the study showed that media advertisements of TV and radio had a significant influence on consumers' purchase intent, while radio and billboard advertisements had significant influence on the attention, interest, desire, conviction, and action (AIDCA) of consumers of Hero beer. The media-mix of radio and billboard mostly influenced consumers' purchase intent of Hero beer. Based on the findings, recommendations were made on the need to adopt the AIDCA theory in the evaluation of the effectiveness of media advertising of other brands of beer on consumers' purchase intent, while more attention is focused on using television medium (infomercials) to encourage consumers to purchase Hero beer. For further testing of the efficacy of the AIDCA theory, further studies should replicate the theory and methodology used in this study, with other media of advertising.
\end{abstract}

Keywords: Radio Advertising, TV Advertising, Billboard Advertising and Consumer Behaviour,

\section{Background to the Study}

\section{Introduction}

Purchasers of consumer products, such as beer, are exposed to numerous advertising stimuli aimed at either creating or increasing awareness, stimulating purchase intent, and generating trial/retrial of the products. There exist other attitudinal and/or behavioural objectives that the advertisements may be aimed at accomplishing. Marketing theory and advertising copyrighting consider advertisements as means of making what may be characterised as complete sales presentations. Marketing practitioners also visualise advertising as an essential promotional tool in formulating promotional strategies (Engel, Blackwell \& Kollat, 1978). CIM (2009) states that "there are three main reasons for advertising - to provide your target audience with information (creating awareness) to persuade them to buy from you (by promoting product and company benefits) to reinforce your existence (by consistently repeating key messages)".

An advertisement, in terms of its constituent elements is expected to have an anatomy comprising of at least four essential elements, as argued by the AIDA (Belch and Belch, 2001) (Attention, Interest, Desire \& Action) and AIDCA theories of advertising, and explained in Anyanwu (2003), Engel, et al (1978) and Parker (2012). AIDCA is an extension of AIDA, a popular advertising construct in advertising. AIDCA is an acronym that stands for Attention, Interest, Desire, Conviction, and Action elements or stimuli that are implicitly and/or explicitly coalesced into what is called an advertisement, targeted at consumers to elicit some desirable promotional and/or sales effect. Typologies of advertising include advertising embodied in physical forms such as billboard, newspaper and magazine advertisement, which typify advertising in its physical form. Radio advertising, for instance, is an example of advertising in an unseen, but heard form. That is audio advertising.

Advertising seems to cut across the entire gamut of consumer products, especially in the so-called developed countries. In Nigeria, the advertising of consumer products is not widespread in the category of 
consumer products, but advertising of beer in Nigeria is noticeably visible in most of the States, including Anambra State. Media advertising and beer advertisement, in particular, is commonplace in places where beer is sold in Anambra State. Media advertising of the Hero brand of beer in Awka, Anambra State, Nigeria is visibly present and loud. There appears to be a dearth of literature on how media advertisements of beer influence consumers' purchase intent of beer. There is also a lack of evidence that the AIDCA theory has been applied to study how media advertising of beer affects consumers' purchase intent of beer.

This study is borne out of the desire to apply a theoretical approach, AIDCA, to analyse the effects of media advertising of beer on consumers' purchase intent of Hero beer. Consequently, the theoretical framework for this study rests on the relationship between media advertising of Hero beer and consumers' purchase intent as evaluated using the AIDCA theory of advertising. The AIDCA theory of advertising essentially posits that the Attention, Interest, Desire, Conviction, and Action elements of an advertisement induce an attitude and/or behaviour in the consumers. The resulting attitudinal and/or behavioural effects could be for the consumers to become aware or more aware of the product, develop purchase intent of the product or purchase/repurchase the product. Purchase intent of the product may ultimately result in actual purchase of the product. Hence, it is salient to study how media advertisement of a consumer product may influence consumers' purchase intent of the product.

\section{Statement of the Problem}

Media advertisement may be effective in stimulating consumers' purchase intent of beer. Consequently, the research problem focuses on the void that may exist due to the non-application of the AIDCA model to study consumers' purchase intent of beer, using media advertisements (TV, radio, and billboard) of Hero beer in Awka, Anambra State.

\section{Objectives of the Study}

The study aims at determining the effects of media advertisements of Hero beer on consumers' purchase intent, using the AIDCA model.

The specific objectives are to:

1. To discover how media advertisements influence the consumers' purchase intent of Hero beer.

2. To determine how media advertisements (TV, radio \& billboard) influence the consumers' attention to Hero beer.

3 To find out if any of the media mix could influence consumers' purchase intent of Hero beer

3. To determine how media advertisements dictate the interest consumers have in Hero beer.

\section{Research Hypotheses}

The following research hypotheses, in null form, were tested to answer the research questions posed in this study:

1. Media advertisements have no influence on the consumers' purchase intent of Hero beer.

2. Media (TV, radio \& billboard) advertisements have no influence on the attention, interest, desire, conviction, and action (AIDCA) of consumers of Hero beer.

3. None of the media mix has influenced the consumers' purchase intent of Hero beer.

\section{Significance of the Study}

The findings of this research will significantly create awareness of the effects of media advertisements on consumers' purchase intent of Hero beer, while stimulating observation of the AIDCA stages.

Identification of the significance of media advertising will contribute to the production of TV, radio, and billboard advertisements with enhanced promotional effects on consumers of Hero beer, and perhaps other beer brands. The study will serve as a piece of motivation to organisations wishing to advertise their beverages. It will also be beneficial to advertising copywriters and managers of beverages. Finally, this study will be of importance to academia as additional literature in the understanding of AIDA, AIDCA, and other extensions of AIDA.

\section{Scope of the Study}

Subject and Variable Scope: The study's subject scope is delimited to marketing communication via media advertising ( $\mathrm{TV}$, radio, and billboard) as an aspect of promotions in marketing, and purchase intent of consumers' of Hero beer with emphasis on AIDCA. The variables of interest in the study are the three aforementioned media advertisements, which can be evaluated using the AIDCA model, and consumers' purchase intent of Hero beer. Media advertising was the independent variable, which was measured using the AIDCA model, while purchase intent was the dependent variable. 
Geographical Scope: Awka, a commercial city and the capital of Anambra State, Nigeria is the geographical area of study.

Study Unit Scope/Brand of Interest: The units of study in this research work consisted of only adult consumers of Hero beer who at the time of this study reside in Awka, and have seen advertising billboards, heard radio advertisements, or seen and/or heard TV advertisements.

\section{Introduction}

\section{Review Of Related Literature}

For close to a century, advertising researchers and practitioners the world over have diligently sought to understand how advertising influences buyers' purchase intentions. The way in which a target audience processes and ultimately uses advertising information to influence product and brand choices is considered a top priority research area for contemporary marketing and advertising researchers.

In the past, advertising and marketing communications went to work only for the purpose of increasing sales, but today one can argue that advertising is considered one of the most important elements of customer service. One of the most important issues in the realm of advertising is evaluation of advertising effectiveness. Advertising changes attitude, increases knowledge, reforms behaviour, informs the audience, strengthens relations, promotes exchanges, and reminds the audience of the various features of a product. This study examines an attitudinal change in purchase intent which may be induced by media advertisements.

\section{Development and Evolution of Advertising Theories}

Barry and Howard (1990) traced the development and evolution of advertising theories when they wrote that: "In 1898, E. St. Elmo Lewis developed AID (Attention, Interest, and Desire) as a sales guide for salesmen to be successful in moving a prospect to buy. Later, AID became AIDA (Attention, Interest, Desire, and Action) when the action stage was considered necessary to convince salesmen to move buyer prospects through complete selling process. In 1910, Printers Ink Editorial developed AICA (Attention, Interest, Conviction, and Action), and argued that a complete advertisement must follow this conjecture of persuasion. In 1911, Arthur F. Sheldon developed AIDAS as Attention, Interest, Desire, Action, and Satisfaction. He added "Permanent Satisfaction" as a necessary part of the persuasive and long-run selling process. In 1915, Samuel R. Hall developed AICCA as Attention, Interest, Confidence, Conviction, and Action as the necessary steps in writing a good, persuasive advertisement. In 1921, Harry D. Kitson developed AIDCA as Attention, Interest, Desire, Conviction, and Action. He used this model in writing about how the mind of the buyer works. In 1940, Clyde Bedell also developed AIDCA, in agreement with Kitson. In 1956, Merrill Devoe developed AIDMA as Attention, Interest, Desire, Memory, and Action".

The first published hierarchy of effects (Belch and Belch, 2001) in advertising was operative in marketing communications since 1898 and researchers and practitioners continue to contest the hierarchy notion till today. The vast majority of them merely offer changes in nomenclature to the traditional hierarchy-of-effects model which hypothesised that audiences respond to messages in a cognitive, affective, and conative (behavioural) sequence. More recently, however, researchers have begun to debate the existence of a single hierarchy sequence and have proposed alternative order hierarchy models, like standard learning, low-involvement, and dissonance/attribution models. Proponents of the traditional hierarchy framework claim that audiences of advertising and other marketing communications respond to those messages in a very ordered way: cognitively first (thinking), affectively second (feeling), and conatively third (doing) (Lavidge \& Steiner, 1961).

Advertising is an investment in a 'long-term' process that moves consumers over time through a variety of stair-step stages, beginning with product 'awareness' and moving ultimately to actual purchase. The view of the stages of the advertising hierarchy is implicitly a casual one. However, by recognising that advertising is essentially a 'long-term' process, it suggests that a casual influence between stages must occur only in the long-run, although it may not be found in the short-run. The argument that a favourable response at one step is a necessary, but not sufficient condition for a favourable response at the next step is central to the idea of advertising hierarchy of response models to this day (Preston \& Thorson, 1983).

Lavidge and Steiner (1961) posit that the Model Stage advertising involves conative, affective, and cognitive while Model Order involves purchase, conviction, preference, liking, knowledge, and awareness. At the conative stage are purchase and conviction; at the affective stage we have preference and liking; at the cognitive stage are knowledge and awareness.

\section{AIDA Advertising Theory}

AIDA was theorised as a behavioural model intended to ensure that an advertisement raises awareness, stimulates interest, and leads the customer to desire and eventually takes action (Hackley, 2005; Nwosu, 
2001). The AIDA theory was seen as highly persuasive and is said to often unconsciously affect our thinking (Butterfield, 1997). AIDA theory suggests that for an advertisement to be effective, it has to be one that commands Attention, leads to Interest in the product, then to Desire to own or use the product, and then finally leads to Action (Mackay, 2005).

\section{AIDCA Advertising Theory}

According to Ugonna, Ndubisi, Otugo, Eze and Akabogu, 2014), the AIDCA theory is very important in both sales and marketing. It stands for the following:

Attention: First, the consumer's attention has to be captured through the advertisement before he can make the necessary approaches towards the purchase of the Hero beer.

Interest: After the attention is elicited the next is that the customer's interest is aroused and a social inclination is imbibed in the product.

Desire: Then, the clientele desires the Hero beer as he perceives it as being capable of satisfying his urge for a beer drink.

Conviction: The customer then earns a conviction within him that the Hero beer will yield the most expected benefit to him.

Action: And he finally make his purchase of the Hero brand of beer having convinced himself of the level of satisfaction he will derive from the consumption of Hero beer.

\section{Advertising}

Advertising is simply the process of creating awareness about the existence of goods and services to a target audience. It is an inertia that is capable of any type of product because of its persuasiveness (Kenechukwu, Asemah and Edegoh, 2013). "An advertisement is defined by the Advertising Practitioners Council of Nigeria(APCON) as a "communication in the media paid for by an identifiable sponsor and directed at a target audience with the aim of transferring information about a product, service, idea or cause" ( Ukaegbu, 2013). According to Nour, Almahirah, Said and Freihat (2014) advertising "is defined as any non-personal communication means of ideas or products by using mass communications media such as television, newspapers, magazines, cinema, radio etc. and is implemented through a specific sponsor, for a fee paid to influence consumer behaviour". According to Benson-Eluwa, V. (2005, p.5), "Advertising is a form of nonpersonal method of communicating information which is usually paid for by a sponsor through various media". Onditi (2012) "defined advertising as any paid form of non-personal communication about an organization, a good, service or an idea by an identified sponsor".

These definitions can tell one that advertising is a persuasive communication, because it tries to persuade the readers, viewers or listeners to take to the sponsor's point of view and also take some appropriate actions towards an object of advertisement (Ukaegbu, 2013). She goes on to add that "in an industrial and free competitive market economy, where the interplay of economic variables dictates the market, the problem of survival of business becomes a very nightmarish one for producers and manufacturers. The singular desire of manufacturers becomes how to create awareness and market for their goods. Advertising is then one strategy that fulfils the desire completely. The desire to be buoyant in business and to increase profit has given advertisement an irrevocable reputation."

Advertising is not undertaken by management just for fun or to keep products or services. It is principally involved in persuasion or advocacy, even apparently just giving us information, using media that are paid for to get through to the mass audience with the identity of the advertisers being clear. "Advertising has the mandate to sell the advertiser's goods and help the consumers to shop wisely" Okoro (1995). Advertising is to communicate information about a good, service or idea and thus stimulate demand. (Ukaegbu, 2013). According to Ukaegbu (2013) "One function of the mass media which is becoming increasingly important in the modern world is the economic functions of advertising. Mass media perform this function for the people by bringing together buyers and sellers through advertisements. Again, the world is fast becoming a common market place of ideas. Many multinational companies have come to realise that people have the same basic needs and desires. Consequently, they have heeded to calls for global marketing and can promote their goods and services using advertisements".

\section{Radio Advertising}

Radio advertising is a form of advertising via the medium of radio. It ability to reach a wider population of consumers scattered over a large geographical area makes it very effective and efficacious, Ti is a good channel for marketing fast moving consumer products like beer (Rajagopal, 2010). Airtime is purchased from a station or network in exchange for airing the commercials. Radio has the limitation of being restricted to sound and proponents of radio advertising often cite this as an advantage. Radio is an expanding medium that can be found not only on air, but also online. 
It is the most economical among other media as it's cheap to buy. Even the poorest man in the remotest pert of Nigeria can afford to purchase a pocket radio and listen to current news. Its audio characteristics makes it a more communication media as both the literate and illiterate can appreciate its means of transmitting news; news can be transmitted in many local languages. Almost all the 36 states in Nigeria have a local radio station and beer advertisement especially the Hero brand can be heard at any time of the day. It is a highly portable medium as it can be carried about conveniently and comfortably without being damaged. Immediacy is another advantage of the radio as the audience access the news and other programmes the very moment they are being broadcast. It has no foreground as one most not be around the radio set to understand what is being said or advertised. Radio has a high believability than the print media in Nigeria (Nwosu and Nkamnebe, 2006). Radio has the disadvantage of being fleeting except for repeated programmes and commercials. It has clutter and the listeners will have to identify a particular beer advertisement from numerous adverts at different time interval. It is known as advertising bombardments. Of course it is an audio medium unlike the television that is audiovisual. By audio, it means that one can only hear but not view a radio advertisement or other programmes.

\section{Television Advertisement}

A television advertisement or commercial is a form of advertisement in which goods, services, organisations, ideas etc. are promoted through the medium of television. Television is an audio-visual medium as goods and services being advertised can be seen by the target audience and this earns it more believability than the radio and print media of advertising. Although it is costlier than the radio, it is regarded as a prestige media as those who can afford a television in Nigeria are regarded as wealthy people. It has immediacy as one of its characteristics too. It also has clutter and is as well transitory like the radio. It is not as portable as the radio. Most advertisements are produced by an outside advertising agency. (Ukaegbu, 2013)

An infomercial is a long-format television commercial, typically five minutes or longer. The main objective of an infomercial is to create an impulsepurchase, so that the consumer sees the presentation and then immediately buys the product through the advertised toll-free telephone number or website. Infomercials describe, display, and often demonstrate products and their features, and commonly have testimonials from consumers and industry professionals (Retrieved from https://www.boundless.com). According to Ukaegbu (2013), advertisers spread commercials across a number of programmes reaching many more viewers. Networks now own different "spot" commercials for many products in the same show. A spot has to stand out and be remembered and this brought about creativity in television advertising owing to the large number of advertisements, and many products with the same quality and cost. The unique selling point and brand awareness became ever more important.

\section{Billboard Advertising}

For a billboard to contribute to the success of a product, it has to be designed so that the customer passes through the five phases of the AIDCA theory, with all being equally important. The AIDCA theory implies that the billboard should inject memorable and believable messages that will trigger consumers to act in a certain way (Brierley, 2002).

Billboard has a high visual impact as large billboards are installed in strategic places and highways all over Nigeria. It has low cost compared with television and radio in terms of production. It also has high product visibility as large pictures of the advertised product can be perceived and understood by anybody without having to ask much questions, hero beer advertisement can be seen in countless billboards across Nigeria. Its disadvantage is that it is only effective outdoors (Nwosu, 2001). Unless one travel out, it is very difficult to see a billboard. Except if one by chance sees it in a TV programme or movie. It can distract a driver on the highway and make him lose concentration on the steering, it wears out easily and litters the environment

\section{Alcohol Advertising and Promotion}

The supply of alcohol, including its production, marketing, and retail sale, can play a significant role in alcohol consumption and problems (Holder, 2000). One effect of this marketing is to create high barriers to entry (Jain, 1994), which in turn contributes to the concentration of market share in the hands of a small number of companies. These companies face a market that, until recently, essentially had been declining or flat for most of the past two decades. To maintain their markets, alcohol companies must continue to invest heavily in advertising and promotion; to expand the market, they must encourage drinkers to switch brands or increase their consumption, or persuade nondrinkers to start drinking. Young people are one audience for their efforts. Although the precise effects of this marketing on individuals are difficult to calibrate, it is increasingly ubiquitous, and reaps benefits from technologies that are at the cutting edge of information societies. The regulatory frameworks for alcohol marketing, in contrast, were developed in the first part of the previous century and have changed little in the interim (Jernigan and O'Hara, 2004). 


\section{Profile of Hero in Nigeria SABMiller}

"SABMiller made an initial investment of over US $\$ 100 \mathrm{~m}$ in the Onitsha brewery that was commissioned on 30 August 2012. In 2014 a decision was made to invest US $\$ 110$ million to increase the current annual capacity from 700000 to 2.1 million hectolitres. The capacity upgrade is due to be completed in 2015. The brewery produces brands including-Hero Lager, Castle Milk Stout, Grand Malt (non-alcoholic), Beta Malt (non-alcoholic)". (en.wikipedia.org).

"The latest amongst the global bigwigs in Nigeria is SABM through its stake in Pabod Breweries Ltd (Port Harcourt) in 2008. In 2012, following the combination of the Castel and SABMiller businesses in Nigeria and Angola, SABM took operational management of the Castel Nigerian business, International Breweries (INTBREW) on the 1st of January 2012. Other acquisitions include, Intafact Beverages Limited (Onitsha), Voltic Nigeria Ltd (Lagos). SABM is the largest beer producer in Africa and 2nd largest brewer in the world with more than 200 beer brands and some 70,000 employees in over 75 countries. It must be said that with recent investment of over US\$100 million in Nigeria, SABM is intensifying its penetration into the Nigerian market through strategic regional approach, the most popular brands currently gaining a lot of patronage in the country include the Trophy and Hero brands with markets in the South Western and Eastern parts of Nigeria respectively. SABMiller saw double-digit lager volume growth in Nigeria in full-year 2014, underpinned by $23 \%$ volume growth in its Trophy lager brand, while Hero lager volumes more than doubled as SABMiller increased capacity at its Onitsha brewery. Non-alcoholic malt beverage volumes also continued to grow strongly. This was reflected in SABMiller's strong earnings for 2014 compared with Nigeria Breweries and Guinness. International Breweries saw its profit surge by 32.46 per cent year on year, for the three-month period ended June 2014" (GTI, n.d.)

\section{Beer Market in Nigeria}

"Beer market is considered one of the fastest growing industries in Nigeria, and it is the most popular of all alcoholic beverages consumed, constituting roughly 96 percent of all alcoholic drinks sold. It contributes about 28 percent of Manufacturing Value Added (MVA). The Industry is a highly concentrated quasi-duopoly by both industry size parameters of labour and output" (Ukaegbu, 2013).

"The Nigeria brewery industry continues to thrive, even as global consumption slows down due to the recent global economic downturn as well as increasing health awareness. Nigeria is Africa's largest alcohol consumer, accounting for $36 \%$ of Africa's formal alcohol market according to Deutsche Bank Market Research. Driven largely by huge consumer market with a population constituting the largest in Africa and a growing middle class with a large number of drinking-age consumers, beer demand and intense competition amongst other driving factors; the Nigeria Beer Industry has recently evolved from a duopoly to an oligopoly with brewing multinationals battling for position in a market that has plenty of room for expansion. The industry has metamorphosed over the years from mere production of bottled drinks to a diversified industry which constitutes a large segment of the food and beverages sub-sector currently accounting for $35.9 \%$ of the growth in the industrial sector, which grew in 2014 by $6.41 \%$ as against $0.87 \%$ in 2013 .

The principal activities of the breweries industry include the production, packaging and sales of alcoholic and malt beverages. Dominant companies include Heineken commanding a $71 \%$ share of the market through its subsidiary, Nigerian Breweries; Diageo with a $27 \%$ market share through its stake in Guinness Nigeria; while SABMiller "a South African brewery giant" has recently joined the fray with its acquisition of Pabod Breweries in 2008 and International Breweries in 2012; has shown strong growth. Others include low end gin manufacturing companies such as Casapreco and other indigenous manufacturers.

Alcohol consumption is a social activity in Nigeria, so $80 \%$ of the country's alcohol sales are on trade. Beer is the most populous alcoholic beverage in the country, making up about $96 \%$ of alcohol sales. Beer importation has been banned to encourage the Nigerian domestic industry. In addition, Indigenous companies engaged in brewing hops are eligible to "pioneer" status, enabling them to a tax holiday of up to seven years.

Figures released by Heineken have shown that the Nigerian beer market is expected to record a compound annual growth rate of 5.6\% between 2011 and 2020. Despite the strong long-term outlook, the industry is going through a tough period at present due to an increase in the cost of living, pressures from foreign exchange rates as well as distribution pressures stemming from security concerns. However, with the continuous expansion of the Nigerian middle class, it is estimated that a current installed capacity deficit of 53 million hectolitres highlights the potential market. In this report, growth drivers and associated limitations in the Nigeria breweries industry are analyzed, its long term growth outlook examined and critical investment opportunities in the industry expatiated" (GTI, n,d.). 


\section{Consumer Behaviour}

Marketers must understand what influences consumer behaviour, such as the consumer buyer process, top influencers, and effective advertising. Effective advertising will aim to influence consumer behaviour at each and every stage of the consumer buying process. There are many different types of advertising that firms can employ to do this. Commercial advertisers often seek to generate increased consumption of their products or services through branding, which involves the repetition of an image or product name in an effort to associate certain qualities with the brand in the minds of consumers.

Kotler and Armstrong (2012) define consumer behaviour as "the buying behavior of final consumersindividuals and households that buy goods and services for personal consumption". The buyer decision model is made up of three levels-the environment, the buyer's black box and the buyer responses. The environment is composed of the marketing stimuli such as four Ps (product, price, place and promotion) and other more external stimuli such as economical, technological, social and cultural. All these affect and influence the consumer; in particular consumers of Hero brand of beer in Nigeria. But particularly, the promotion aspect is of much concern as the study deals with effect of advertising on the consumer of Hero lager beer. Advertisement is aired towards the consumer and the ad message enters the consumer's black box where a lot of perception, spadework, thinking and brainstorming are done before the consumer could progress to making a rational choice of choosing Hero beer. As the ad message enter the consumer's black box, a lot of influences are impacted on the consumer and these influences include; cultural influences (culture, sub-culture and social class), social influences (reference group, family and roles and status), personal influences (age and life cycle stage, lifestyle, occupation, personality and self concept) and finally, psychological influences (motivation, perception, believes and attitude and learning). The moment the consumer is influenced by many or a few of these, a decision ensues (Kotler and Armstrong, 2012). There exists limited knowledge of factors influencing beer drinkers in Hungarian beer market (Hajdu, Major and Lakner, 2007).

However, making buying decision is not as simple as it might look from the superficial level. A whole lot of process might be made which might be different from different consumer depending on whether he is a first time consumer or a habitual drinker of Hero brand of beer. The process of decision making include-need recognition, information search, evaluation of alternatives, purchase decision and post purchase behaviour. It simply means that a Hero consumer first of all gains appetite by recognising the need to drink Hero. Then he tries to gain information on where, when, who and how much it will take him to buy a bottle or more at a particular time. Of course there are many brands of beer competing with Hero but the fact that he has seen the Hero advertisement for Hero brand whose unique selling proposition is ........, he becomes selectively exposed to it and chooses to select Hero. He therefore buys the Hero and enjoys it. If at the end of the consumption he is satisfied, he makes a repeat purchase any other time he hungers for beer. This repeat purchase attitude makes the consumer brand loyal (Akabogu, 2013).But if on the contrary, he suffers what is known as cognitive dissonance in which Hero has fallen short of his expectation. At this occasion, the likelihood of searching for a better brand of beer maybe Star, Gulder, Guiness Stout etc will emanate.

Alcoholic drink especially beer beverage is enjoyed in every nooks and crannies of Nigeria. They are consumed by the youth as a form of youthful exuberance and also during wedding, burial and other ceremonies (Dumbili, 2013). "Nigeria alcoholic beverage (beer, wine and spirit) market is valued at $\$ 2$ billion and has maintained an annual average growth of 6 percent since 2007" (Ogbeide and Ele, 2015). Advertisement influences consumers to purchase goods and services that ordinarily he may not want to buy (Agwu, Ikpefan, Atuma and Achugamonu, 2014). This is because advertisement creates awareness and passes relevant information to the consumer at every contact point. Amadi and Sunday (2013) infer that consumers of beer must be communicated through advertisement on the benefits the brand offers. Television advertisements influence consumer to buy alcoholic drink (Ugochi, 2013).

\section{Empirical Studies on Media Advertisements}

According to an empirical study on streaming media advertising which utilised the eye-tracking technology to investigate consumers' behavioural responses in three different streaming media advertising forms, eye-movement data of thirty-two undergraduates and postgraduates were collected as they viewed four different types of streaming media advertisements on Web pages coded in Chinese. The result of the study showed that audiences were more sensitive to streaming media advertising when they were in the information search scenario (Shan et. al., 2013). 
Results from another study carried out to determine the effect of media advertising on consumer perception of orthodontic treatment quality, showed that $14 \%$ to $24 \%$ of respondents, felt that advertising orthodontists would offer a lower quality of care than non-advertising orthodontists. Newspaper, magazine, and direct mail advertisements were viewed more favourably than radio, television, and billboard advertisements (Edwards, et al., 2008).

According to results from another related study on the influence of television on consumer buying habits of Guinness stout in Ikeja community of Lagos State, television was viewed as the most preferred medium of advertisement of Guinness Stout (Ukaegbu, 2013).

\section{Introduction}

\section{Research Methodology}

Quantitative methodology, as discussed by Malhotra (2007), was adopted for this study. This methodology permits the use of quantitative data obtained through a structured data collection instrument. Unlike qualitative methodology, quantitative methodology permits the use of statistical analysis to make inferences and recommendations.

\section{Research Design}

The research design used for this study is the survey method. This involves the use of a descriptive, single cross-sectional design, using a non-probability sampling method; the convenience sampling method. The quantitative methodology used assumed that the influence of the advertising elements on consumers' purchase intent and AIDCA were regarded as variables from which means and variances were obtained for statistical analysis.

\section{Population of the Study}

Only adult beer consumers who at the time of this study reside in Awka, and have seen some media advertisements of Hero beer, were used as respondents for this study. The population of Anambra State is estimated to be about 4.1 million people, which is about $3 \%$ of Nigeria's population of about 140.5 million people (Nigerian Population Commission, 2006).

\section{Sampling and Sample Size}

No available database of the qualified population for the study was found at the time of this study. Since there was no sampling frame, the convenience sampling method was used to obtain a sample size of 200 , as suggested by Malhotra (2007). Data, through the convenience sampling method, were obtained from beer consumers at hotels, restaurants, road-side food joints, and places where beer is sold and consumed in Awka, Anambra State, Nigeria.

A structured questionnaire was used to collect data on the influence media advertisement has on consumers' purchase intent and AIDCA.

\section{Reliability and Validity of the Data Collection Instrument}

Reliability: A convenience sample of 20 beer consumers was used to pre-test the questionnaire, and calculate the correlation coefficient, an estimate of the reliability of the data collection instrument. Using Pearson correlation coefficient, a correlation coefficient of .85 was obtained, thus indicating a high reliability of the instrument.

Validity: The questionnaire had to undergo face and contentvalidity before being administered on the respondents. The content validity was estimated as the questionnaire items were scrutinised by three marketing practitioners in Awka, Anambra State.

\section{Data Collection}

Source and Type of Data: Primary data were collected from a judgementally determined sample of 200 respondents from the qualified population of beer consumers in Awka. The questionnaire was used to collect primary data from the sample of qualified respondents in the population. Using the convenience method, the questionnaire was administered to these respondents in a face to face setting in fast food restaurants, hotels, street-side food joints, and other places where beer is served. The respondents were politely requested in those areas to participate in the study, if they chose to. No other means of data collection was used in this study.

\section{Procedures and Analytical Techniques}

The hypotheses in this study were tested by using computerised regression analysis to determine the effect of media advertising on consumers' purchase intent of Hero beer in Awka, while evaluating the influence of media advertisements on consumers' attention, interest, desire, conviction, and action (AIDCA). 
Media advertising, via TV, radio, and billboard, was the independent variable, while purchase intent and AIDCA were the dependent variables. The following methods were used to evaluate the hypotheses under study:

\section{i. Coefficient of Determination}

R-Squared (R2): This measured the percentage of variation in the dependent variables (purchase intent and AIDCA) attributable to the independent variables (media advertisements).

\section{ii. Regression Model}

The regression analysis is a statistical tool for the investigation of relationships between two variables (one dependent and one independent). A linear two-variable regression model was used to test the effect of media advertising on purchase intent and the AIDCA model.

\section{Introduction}

\section{Results And Discussion}

Data were analysed by SPSS. Factor Analysis was first run to determine the extent to which media advertising stimulated consumers to observe the AIDCA stages in the attempt to discover their effect on purchase intent after being exposed to any/all of the forms of media advertising. This was done to determine if AIDCA, (attention, interest, desire, conviction, and action) were congruent with each other and how well they matched up together. Factor analysis showed that each AIDCA stage was congruent with the others.

After looking at the Factor Analysis, it was concluded that the congruency questions needed to be separated into three groups to test three hypotheses. Question \#1, was separated from questions \#2-6, and \#7.

The first two research hypotheses were tested using computerised linear regression analysis, while the third research hypotheses was analysed with computerised descriptive statistics. Below are the results of the study:

Table 1: Regression Analysis of Media Advertising on Purchase Intent

\begin{tabular}{|l|l|l|l|l|}
\hline Independent Variables & B-Coefficient & Std Error & t & P-Value \\
\hline TV & .18 & .06 & 3.0 & .005 \\
\hline Radio & .50 & .05 & 9.0 & .000 \\
\hline Billboard & .19 & .06 & 3.3 & .001 \\
\hline
\end{tabular}

Dependent Variable: Purchase Intent

Note: Significant levels: $* * p<0.05$

$\boldsymbol{H o}_{1}$ : Media advertisements (TV, radio, and billboard) have no influence on the consumers' purchase intent of Hero beer.

In testing $\mathrm{Ho}_{1}$, the linear regression model was used to examine, through computerised data analysis, the independent variables (media advertisements) that may significantly influence consumers' purchase intent of Hero beer. Table 1 shows the results of the computerised linear regression analysis in which all the variables emerged as significant influences, except TV which was not too significant at the .05 level of significance.

Table 2: Data Analysis of Media Advertisements' Influence on AIDCA

\begin{tabular}{|l|l|l|l|l|}
\hline Independent Variables & B-Coefficient & Std Error & t & P-Value \\
\hline TV & .23 & .06 & 3.73 & .000 \\
\hline Radio & .43 & .05 & 9.00 & .000 \\
\hline Billboard & .16 & .06 & 2.73 & .007 \\
\hline
\end{tabular}

Dependent Variable: AIDCA

Note: Significant levels: $* * p<0.05$

$\boldsymbol{H o}_{2}$ : Media (TV, radio \& billboard) advertisements have no influence on the attention, interest, desire, conviction, and action (AIDCA) of consumers of Hero beer.

Table 2 contains the computerised data analysis of the independent variables of TV, radio, and billboard that may significantly influence the attention, interest, desire, conviction, and action (AIDCA) of consumers of Hero beer. The table shows that all but one of the variables emerged as significant influences at the .05 level of significance. Hence, two out of the three media advertisements (TV and radio) had significant influence on the attention, interest, desire, conviction, and action (AIDCA) of consumers of Hero beer.

Table 3: The Influence of Media-Mix Advertisements' Influence on Consumer Purchase Intent

\begin{tabular}{|l|l|}
\hline Media-Mix & No. of Responses \\
\hline Television only & 25 \\
\hline Radio only & 15 \\
\hline Billboard only & 15 \\
\hline Television \& Radio only & 20 \\
\hline
\end{tabular}


Effects Of Media Advertising On Consumers' Purchase Intent In Awka, Anambra State: A Study....

\begin{tabular}{|l|l|}
\hline Radio \& Billboard only & 66 \\
\hline Television \& Billboard only & 34 \\
\hline Television, Radio \& Billboard & 25 \\
\hline
\end{tabular}

$\boldsymbol{H o}_{3}$ : None of the media mix has influenced the consumers' purchase intent of Hero beer.

\section{Media-Mix}

\begin{tabular}{|l|l|l|l|}
\hline & No. of Responses & Frequency & Percent \\
\hline Television only; TV, Radio \& Billboard & 25 & 2 & 28.6 \\
\hline Radio only; Billboard only & 15 & 2 & 28.6 \\
\hline Television \& Radio only & 20 & 1 & 14.3 \\
\hline Radio \& Billboard only & 66 & 1 & 14.3 \\
\hline Television \& Billboard only & 34 & 1 & 14.3 \\
\hline
\end{tabular}

Descriptive Statistics

\begin{tabular}{|l|l|l|l|l|l|}
\hline & N & Minimum & Maximum & Mean & Std. Deviation \\
\hline Media Mix & 7 & 15 & 66 & 28.6 & 17.8 \\
\hline
\end{tabular}

The tables above show that the media-mix of radio and billboard mostly influenced consumers' purchase intent of Hero beer. Hence, one of the media-mix had influence on the consumers' intent to purchase Hero beer.

\section{Discussion of Findings}

The findings of the study showed that media advertisements of radio and billboard had significant influence on the purchase intent of the consumers of Hero beer. Two out of the three media advertisements (TV and radio) had significant influence on the attention, interest, desire, conviction, and action (AIDCA) of consumers of Hero beer. As regards the most influential media-mix, that of radio and billboard mostly influenced consumers' purchase intent of Hero beer.

\section{Conclusion}

\section{Conclusion And Recommendations}

Given the analysis in chapter four and subsequent interpretation of results, this study concludes that media advertisements (TV and radio) of Hero beer had significant effect on consumers' purchase intent. The AIDCA theory, as an advertising paradigm, was significant and relevant in understanding consumer's purchase intent of Hero beer in the study area, based on two of the three types of media advertisement (radio and billboard). The media-mix of radio and billboard mostly influenced the intent to purchase Hero beer.

\section{Recommendations}

Given the findings and conclusion reached in this study, the following recommendations are worth considering:

i. Marketers should create awareness of the effects of media advertisements on consumers' purchase intent of beer.

ii. More attention should be focused on using television medium (infomercials) to encourage consumers to purchase Hero beer.

iii. The elements of the AIDCA theory should be considered as useful tools in the evaluation of the effectiveness of media advertising. Hence, marketers should adopt the AIDCA theory in the evaluation of the effectiveness of media advertising on consumers' purchase intent.

iv. Consumers of beer should be encouraged to evaluate their purchase intent with the aid of the AIDCA theory of advertising, to determine whether any, some, or all of the elements are responsible for their purchase of goods.

v. Finally, managers of beverages and organisations wishing to advertise their beverages should take advantage of media advertising so as to enhance promotional effects on consumers of Hero beer, and perhaps other beer brands.

\section{References}

[1]. Agwu, M.E., Ikpefan, O.A., Atuma, O. and Achugamonu, B.U. (2014) "Conceptual Review of the Effects of Advertising on Consumer Buying Behaviour” International Review of Social Sciences Vol. 2 Issue.11.

[2]. Akabogu, O.C. (2013) "Application of the "Brand-Choice Sequences" Theory to Measure Brand Loyalty to Beer Brands in Nigeria" American Journal of Business and Management Vol. 2, No. 3.

[3]. Amadi, C. And Sunday, E.M. (2013) "Factors Influencing Brand Preference of Beer Consumption in Port-Harcourt Metropolis, Rivers State, Nigeria" European Journal of Business and Management, Vol.5, No.17.

[4]. Anyanwu, A. (2003) AIDA: Promotional Strategy - a Schematic Approach. Owerri, Imo: Alvan Global Publications. 
[5]. Barry, T. E. and Howard, D. J. (1990) “A Review and Critique of the Hierarchy of Effects in Advertising."'International Journal of Advertising, 9.

[6]. Belch, G.E. and Belch, M.A. 2001. Advertising and Promotion-An Integrated Marketing CommunicationsPerspective (5th Ed), New York: Irwin/McGraw Hill.

[7]. Benson-Eluwa, V. (2005) Advertising principles and practices. Virgin Creations, Enugu: Nigeria. Brierly, (2002) The Advertising Handbook, Routledge, London: UK.

[8]. Butterfield, L. (1997) Excellence in Advertising, The IPA Guide to Best Practice. British Library Cataloguing, Oxford: UK.

[9]. CIM (2009) "How to Achieve an Effective Promotional Mix", Retrieved on 20/09/2016 from www.cimco.uk.

[10]. Dumbili, O. (2013) "Changing Patterns of Alcohol Consumption in Nigeria: An Exploration of Responsible factors and Consequences" A Journal of the BSA MedSoc Group Vol. 7 Issue 1.

[11]. Edwards D. T., Shroff, B., Lindauer, S. J., Fowler, C. E. and Tufekci, E. (2008)Media Advertising Effect on Consumer Perception of Orthodontic Treatment Quality; Retrieved on 12/09/2016 from www.ncbi.nlm.nih.gov.

[12]. Engel, J. F., Blackwell, R. D., and Kollat, D. T. (1978) Consumer Behaviour (3rd edition) Homewood, Illinois: Richard D. Erwin, Inc.

[13]. GTI (n.d.) “A Focus on Nigeria Brewery Sector”Retrieved on 09/01/2015 from www.proshareng.com.

[14]. Hackley, C. (2005) Advertising and Promotion: Communicating Brands, SAGE, London.

[15]. Hajdu, I., Major, A. And Lakner, Z. (2007) "Consumer Behaviour in the Hungarian Beer Market" Studies in Agricultural Economics No. 106.

[16]. Jernigan, D. and O'Hara, J. (2004) "Reducing Underage Drinking: a Collective Responsibility."National Academy of Sciences. National Center for Biotechnology Information, Rockville Pike, USA.

[17]. Kenechukwu, S.A., Asemah, E.S. and Edegoh, L.O.N. (2013) "Behind Advertising: The Language of Persuasion "International Journal of Asian Social Science, 2013, 3(4).

[18]. Kotler, P. and Armstrong G. (2001), Principles of Marketing, (9th Ed), New Jersey: Prentice Hall Inc.

[19]. Lavidge, R. J. and Steiner, G. A. (1961) “A Model of Predictive Measurement of Advertising Effectiveness.”Journal of Marketing, 52.

[20]. Mackay, A. (2005) The Practice of Advertising (5th edition) Elsevier Butterworth-Heinemann, Sydney: Australia.

[21]. Malhotra, N. R. (2007) Marketing Research, an Applied Orientation (5th edition) New Jersey: Pearson Prentice Hall.

[22]. Nour, M.I., Almahirah, M.S., Said,S.M. and Freiha, S. (2014) "The Impact of Promotional Mix Elements on Consumers Purchasing Decisions" International Business and Management, Vol. 8, No. 2.

[23]. Nigerian Population Commission (2006) Data for National Development, Retrieved on 23/01/ 2013 from www.population.gov.ng.

[24]. Nwosu, I. E. (2001) Marketing Communication Management and Media Lagos: Dominican Publishers (Afri Tower Ltd).

[25]. Nwosu, I.E. and Nkamnebe, A.D. (2006) Triple-P Advertising; Principles, Processes, Practices,

[26]. Aba: Afri-Towers Ltd.

[27]. Ogbeide, O.A. and Ele, I. (2015) "Nigeria Wine Market: The Implications of Consumers' Socio-demographics and Preference" Mayfair Journal of Agriculture Development in Emerging Economies (MJADEE).

[28]. Okoro, N. (1995) The Business of Advertising, (1st edition). Acena Publishers,Onitsha: Anambra.

[29]. Onditi, A.A. (2012) “An Evaluation of Promotional Elements Influencing Sales of An Organization: A Case Study of Sales of Agricultural and Non-Agricultural Products Among Women Groups, Homa Bay District, Kenya”. International Journal of Business and Social Science Vol. 3 No.5.

[30]. Parker, M. (2012) AIDCAS Retrieved on 09/05 2014 from www.mindtools.com.

[31]. Preston, I. L. and Thorson, E. (1983) "Challenges to the Use of Hierarchy Models in Predicting Advertising Effectiveness." Proceedings of the Annual Convention of American Academy of Advertising, 27, 33.

[32]. Rajagopal (2010) "Role of Radio Advertisements as Behavioral Driver among Urban Consumers" Retrieved on 08/08/2014 from www.sibresearch.org.

[33]. Shan, S., Mao, Z., Zhou, R., Liu, Z. and Wu, F. (2013) Streaming media advertising: An empirical study. 30 (3).

[34]. Ugochi, U.V. (2013) “ Influence of Television Advertising on Consumer Buying Habits of Guinness Stout in Ikeja Community of Lagos State" B. Sc Thesis Department Of Mass Communication, Faculty Of Management And Social Sciences, Caritas University, Amorji - Nike, Enugu.

[35]. Ugonna, I.A., Ndubisi, E.C., Otugo, N.E., Eze, P.C. and Akabogu, O.C. 2014) "Anatomical Effects of Billboard Advertising on Consumers' Purchase Intent of Beer" International journal of Innovative Research in Management, Issue. 3 volume 7.

[36]. Ukaegbu, U. V. (2013) Influence of Television Advertising on Consumer Buying Habits of Guinness Stout in Ikeja Community of Lagos State. A research Thesis; Caritas University, Amorji - Nike, Enugu. 